\title{
Building the Professional Identity of Research Assistants: A Phenomenological Research
}

\author{
Hilal Büyükgöze ${ }^{1}$ \\ Hacettepe University
}

\author{
Feyza Gün² \\ Hacettepe University
}

\begin{abstract}
This research aims to investigate the determining factors in how research assistants build their professional identity. In the study, which is a qualitative research method patterned on phenomenology, data was collected using a semi-structured interview form. Structured interviews were conducted with seven research assistants selected from a faculty of education at a state university in Ankara using the criterion sampling method. According to the research results, research assistants were determined to prefer taking faculty members as their role models in building their professional identity. They see this process as an opportunity to specialize in their field and improve themselves, feel that working at a pioneering university with prestige in its field increases their responsibilities, and are more enthusiastic about improving themselves in that direction. In relation to deficiencies in the process of building their professional identity, the participants stated that they have limited opportunities regarding practice and feel uncomfortable conducting research unrelated to their practice. The research results were discussed in the context of related literature, as well as the administrative and functional structure of the higher education system.
\end{abstract}

\section{Keywords}

Higher education • Professional identity • Building professional identity • Research assistant •

Phenomenology

\footnotetext{
" This study was conducted in partial fulfillment of the requirements for Literature Review and Report Writing course, and the authors would like to express their grateful thanks to Dr. Nihan Demirkasımoğlu, the instructor of the course, for her critical approach and invaluable help in the study.

1 Department of Educational Sciences, Faculty of Education, Hacettepe University, Ankara, 06800 Turkey. Email: hilal.buyukgoze@gmail.com

2 Correspondence to: Feyza Gün, Department of Educational Sciences, Faculty of Education, Hacettepe University, Ankara, 06800 Turkey. Email: feyzagun7@gmail.com
}

Citation: Büyükgöze, H., \& Gün, F. (2017). Building the professional identity of research assistants: A phenomenological research. Educational Sciences: Theory \& Practice, 17, 237-263. http://dx.doi.org/10.12738/estp.2017.1.0216 
Higher education institutions, which have a significant function in raising the qualified labor that will play a significant role in a country's development, are organizations with various duties and responsibilities such as carrying out scientific research, producing information and technology, offering solutions to social and universal problems, setting examples in every field, and presenting innovative, critical perspectives. Higher education institutions, being at the top of the education system, play a determining role in professional life and personal development. Faculty members, who are responsible for fulfilling the duties of higher education institutions related to their objectives, are leading actors for these institutions. Because the success of a higher education institution is related to the success and performance of the faculty members working in that institution (Daresh \& Playko, 1995), effective faculty members are required. Universities have the most significant task of developing qualified faculty members. By means of postgraduate programs, which are considered one of faculty members' most important resources for universities (Karakütük \& Özdemir, 2011, p. 29), they aim to raise qualified scientists who acquire research culture, can respond to the needs of an evolving society by contributing knowledge through research, and are professionally well-equipped and specialized in their fields (Ünal \& İlter, 2010; Varış, 1972). Given that professionals with a strong professional identity are required for a field to achieve professional status and offer qualified services (Strasen, 1992), research assistants can be expected to try and build a professional identity during their postgraduate education.

\section{Conceptual Framework}

Post-Fordism, which came into effect in the last quarter of the 20th century, has made its presence felt in every field and has brought along both social and economicpolitical transformations (Demirel \& Yegen, 2015; Glyn, 1990; Memduhoğlu, 2007; Vidal, 2011). With these transformations, which were also reflected in the social sciences, new arguments have been developed in relation to race, ethnicity, culture, rights, and identity. From this view, research based on industrial and organizational psychology through the socio-psychological aspects of identity phenomenon or through discussions on employee behaviors (i.e., Albert, Ashforth, \& Dutton, 2000; Cole \& Bruch, 2006) have been frequently addressed since the 1970s.

Identity phenomenon is basically discussed in the context of two theories: identity theory and social identity theory. Identity theory examines social behavior in the context of mutual relations and interactions between the individual and society (Burke, 1980; Stryker, 1968). It claims that society influences social behavior by affecting the individual and discusses society as consisting of differences but with a basic order; in other words, it has an organized structure (Stryker \& Serpe, 1982, p. 206, as cited in Hogg, Terry, \& White, 1995). Identity theory is founded on this 
assumption about society. Similarly, Utku (2014) emphasized that individuals have various multilateral identities as a reflection of their society, and personality has a micro-sociological organized structure that consists of these different identities.

Stryker (1968), who first mentioned identity theory, stated that role identities cannot be chosen freely by individuals but, on the contrary, are imposed by society. The theory indicates the presence of "supra-identities" that determine which one of these identities are more superior and applicable, in addition to role identities (Madran, 2011). The hierarchy of identities within one's self directs the individual's behaviors. The most effective supra-identity is the one on top of the hierarchy (Atak, 2011). This identity is mostly the one related to the role in the strongest and most intense social environment where the individual wants to prove one's devotion. For example, of two people who are both fathers and research assistants, one may continue academic studies on the weekend whereas the other spends time with their child.

Social identity theory, which was first shaped by Tajfel and Turner (1986), prioritizes group membership, in-group processes, and the relations and interactions among groups (Burke, 1980; Hogg et al., 1995). The theory suggests that the selfperceptions of individuals who belong to a group change within the group and that individual identity gives way to social identity when group membership is meaningful to them because people recognize, classify, and explain their position within society for both themselves and other people by means of the groups of which they are members (Stets \& Burke, 2000). Also, the groups that people belong to around an individual, as well as the group to which the individual belongs, enable individuals to understand their position within the social structure by means of in-group and outside-of-group comparisons (Hains, Hogg, \& Duck, 1997). Furthermore, while one is included in a group, the individual may search for new groups that are thought able to contribute to one's social identity (Riley \& Burke, 1995). If one thinks that the group doesn't contribute positively to their social identity, they can leave that group (Tsushima \& Burke, 1999). Therefore, social identity is based on preferences; it is dynamic, not obligatory. Despite their distinct aspects, both theories can be said to include individuals' identities in a social environment, their role-driven behaviors, and their dynamic, multilayered personality traits (Utku, 2014).

In the context of organizational life, the phenomenon of professional identity can be said to stand out over identity or social identity. Henkel (2000, as cited in Clarke, Hyde, \& Drennan, 2013) mentions three components of professional identity: having a certain background or history, existing within the framework of selected ethics or values, and positioning one's self within a society or organization because of its qualities. Building a professional identity is described as a continuous reinterpreting and structuring of these components through professional training and experience 
(Kogan, 2000). In this respect, when reviewing the literature on employee identity and building an identity in organizational life, one sees a limited number of studies on how identity is built in professional life, although there are numerous studies that address the phenomenon of identity (Atak, 2011; Ibarra, 1999; Pratt, Rockman, \& Kaufmann, 2006). It is possible to analyze studies on building a professional identity in three main categories (Pratt et al., 2006, p. 236): (a) career transition, (b) organizational socialization, and (c) intentional identity building.

The point of view that describes how to build a professional identity through a career or role transitions/changes, emphasizes that identity can change in an organizational context as one's career progresses. For example, Hall (1995) stated that individuals need to transform and assume new roles throughout their careers. He argued that such transitions occur as a result of certain social identities or role expectations. However, although Hall (1995) emphasized the importance of competence as perceived by the individual in these transitions, he did not provide an explanation on how the content of identity changes in this process. West, Nicholson, and Arnold (1987) mentioned four outcomes in the context of professional identity building while employees switch to their new role identities: absorption, determination, exploration, and replication. These outcomes are said to indicate a change in the individual, the role-identity one possesses, or both.

Archer (2008) reported that the professional identity building of young academicians takes place in parallel with their careers related to their personal identity. Similarly, Reynolds (1996) quoted that role transitions, which consist of the environment in which one exists, the environments' expectations from the individual, and what the individual allows the self to be affected by, continue throughout individuals' careers; this circumstance can be effective in shaping professional identity. At the same time, the learning that occurs during university education (Hunter, Laursen, \& Seymour, 2007), self-awareness/consciousness (Barrow, 2006; Baxter Magolda, 2004; KaartinenKoutaniemi \& Lindblom-Ylänne, 2008), analyzing reflections on life (Bramming, 2007; Cherry, 2005; Klenowski, Askew, \& Carnell, 2006), and effective academic mentorship are significant in founding professional-identity building. However, as learning at work increases along with the transition from student life to work life, university learning is replaced with on-the-job learning on the basis of professional identity. However, Chapman and Pyvis (2006) reported that completing a university program in any field has quite an impact on an individual's professional identity.

Studies that present individual's professional identity building within an organization take place by means of organizational socialization and constitute another main topic in this literature. Tierney and Rhoads (1994) defined organizational socialization as "a ritualized process that contains mutual cultural transfer between the organization and 
individuals" (p. 21). The authors also noted that socialization in universities consists of two stages, anticipated and organizational. Anticipated socialization takes place when the individual observes and adopts the attitudes, actions, behavioral norms, and values of the academicians in one's field during postgraduate education (Sweitzer, 2009). According to the author, organizational socialization occurs when a faculty member starts their academic career and is structured on anticipated socialization. However, this stage is also mostly framed by the experiences acquired during anticipated socialization. Professional identity will be built quicker and easier if the organizational socialization stage is in line with the experiences that an individual has acquired during anticipated socialization, organizational culture, and organizational structure. However, in case of differences, various factors such as organizational climate and the new institution's culture can attempt to change what individuals have brought with them in the background (Tierney \& Rhoades, 1994).

Social networks that organizational socialization have brought forth are reported to have career-oriented outcomes such as job satisfaction (Podolny \& Barron, 1997), promotion and progress (Burt, 1992), and overall career achievement (Guiffe, 1999; Sweitzer, 2009). As such, Ibarra, Kilduff, and Tsai (2005) stated that social networks might be benefited from as identity-building mechanisms. The last point to mention in that respect is that gender has a significant role in accessing social networks. In that direction, Rogers (2000) stated that professional networks in academic life are still mostly sexist for women. In terms of establishing, maintaining, and accessing top-level networks, women have a less advantageous position compared to their male colleagues.

Other studies in the literature on building a professional identity discuss how identity is directly structured by the individual. These studies generally focus on individuals' active identity building within a social context. In structuring the identity, career and role transitions take place more interactively and in a relatively more problematic manner, not just by means of transitioning to certain roles as in the literature (Dickie, 2003; Ibarra, 1999). In that respect, the individual may prefer taking a role model and structure one's identity in that direction (Ibarra, 1999). However, the individual may also build a professional identity on one's own by actively structuring it and working on it through trial and error (Pachler \& Daly, 2003; Wrzesniewski \& Dutton, 2001).

Understanding how a professional identity is built, with its complex, personal, and contextual qualities (Clarke et al., 2013; Henkel, 2009, p. 9), is just as important for universities as is it for any other organization. In that context, Henkel defines the theoretical structuring of professional identity in universities by means of three concepts. The first concept is the distinctive individual (Moore, 2001) and is expressed as one who has an authentic background or history, positions one's self 
within the framework of the ethics or values of their choosing, and identifies with a certain community or organization with the same qualities as the individual. In this respect, academicians seek a response to the individual's needs in relation to respect and recognition. These three components that constitute the concept of a distinctive individual enable academicians to become effective professionals. These components strengthen and mature within the process by means of professional training and experience (Henkel, 2002).

The second concept in Henkel's (2000, as cited in Henkel, 2009) framework on professional identity is the embedded individual. Each distinctive individual is also an embedded individual. Everybody is somehow a member of a community or organization with distinctive language, context, history, traditions, values, practices, and features. Accordingly, Henkel argues that individuals mostly adopt and implement certain roles wherein the communities and organizations that individuals are members of are great determinants.

The last concept in this framework is the professional identity. Professional identity has both individual and social aspects. On one hand, while people strengthen individually by means of the specialized knowledge they have and the framework of their ethics or values, on the other hand, they as members do not neglect playing the roles dictated by their community. In summary, the professional identity has a structure in which these three components continuously interact; it is interpreted and explained again and again with the knowledge and experience acquired throughout the process.

As stated by Rhoades (2007) and Henkel (2009, p. 3), there is insufficient evidence available to comprehend the related experiences and organizational background in terms of how academic personnel working in universities build their professional identity and make reliable inferences. The process of how research assistants, who are young academia members and considered to be intellectual capital with a future say who will work in critical positions in managing higher education in the future, build and continue to structure their professional identity is seen to contain a variety of challenges. On this point, the current study focuses on analyzing professional identity with its behavioral, affective, and cognitive reflections for both the individual and the organization within the context of the conceptual framework suggested by Henkel (2000) over research assistants in their first stage in universities. Although there are various identity theories regarding different professional groups in the literature, Henkel's approach is preferred as it provides a conceptual framework in direct relation to how academicians build their professional identity. From this point, the primary aim of the study is to investigate the determining factors in research assistants' professional identity building. In accordance with this aim, the study seeks answers to the following questions: 
1. What do research assistants think about the concept of faculty member?

2. What factors caused the research assistants to choose their profession?

3. What kind of a faculty member do research assistants want to be in the future?

4. To what extent is the postgraduate education process (courses, counseling, support from other faculty members, etc.) a determinant in building research assistants' professional identity?

5. What kinds of practices do the (a) university, (b) faculty, (c) department, and (d) division have in relation to how research assistants build their professional identity?

6. What deficiencies do research assistants see when building their professional identity?

\section{Method}

\section{Research Design}

The study adopted the phenomenological design, a qualitative research method. While phenomenological designs deal with a small number of people who question the meanings they infer from their experiences regarding a phenomenon or concept, they also focus on defining features common to all participants who experience this phenomenon (Cresswell, 2013, p. 77). Baş and Akturan (2008) stated that phenomenological studies investigate the individual experiences and perceptions of participants who have experienced a certain phenomenon, as well as the meanings they attribute to these experiences. This study uses a phenomenological design because it aims to present and depict how research assistants build their professional identity in detail based on their own perceptions and depictions. The phenomenon addressed in this study is how one builds a professional identity.

\section{Participants}

The study group consists of seven research assistants working at a state university in Ankara during the fall semester of the 2015-2016 academic year. Participants in the study group were determined using the criterion-sampling method, one of the purposeful sampling methods, according to their length of service (Patton, 2014). In this study, which considers this criterion to be a significant variable that affects research assistants' experiences and views, their observations on the investigated phenomenon is thought to perhaps extend over a longer time, and thus they may have encountered more examples and acquired more experience. The participants were required to have worked as research assistants for at least three years. Research assistants who were 
included in the study group were identified primarily by taking into consideration their length of service and then their branch, gender, and age. Ensuring maximum diversity was intended when selecting participants to reflect the diversity and contributions of individuals who might be a part of the problem, as examined on the basis of a small sample which was formed at a relatively maximum level (Fraenkel \& Wallen, 2006, p. 440). Participants' demographics are given in Table 1.

Table 1

Participants' Characteristics

\begin{tabular}{ccccc}
\hline Participant Code & Tenure (Year) & Branch & Gender & Age \\
\hline RA1 & 10 & Educational Administration & F & 34 \\
RA2 & 4 & Assessment and Evaluation in Education & M & 27 \\
RA3 & 4 & Secondary Education Science and Mathematics & F & 27 \\
RA4 & 9 & Teaching & F & 33 \\
RA5 & 4 & Psychological Counseling and Guidance & M & 29 \\
RA6 & 6 & Primary School Teaching & F & 30 \\
RA7 & 3 & Curriculum and Instruction & M & 27 \\
\hline
\end{tabular}

As can be seen in Table 1, the study was conducted with the participation of research assistants (RA) from seven separate departments. In this respect, participants' length of service varies from three to 10 years and their ages are between 27 and 34 . Four participants are female and three participants are male.

\section{Data Collection Tool}

In the study, data was collected using a semi-structured interview form, one of the most useful tools for collecting information to test the researcher's assumption (Fraenkel \& Wallen, 2006, p. 455). While creating the data collection tool, the conceptual framework suggested by Henkel (2010, as cited in Clarke et al., 2013) on the basis of the communitarian-collectivist philosophical approach was adopted in relation to the process of building a professional identity (Kogan, 2000, p. 209). The research questions "What do research assistants think about the concept of faculty member?" and "What factors caused the research assistants to choose this profession?" were prepared to present views regarding the distinctive individual aspect. The question "What kind of a faculty member do research assistants want to be in the future?" was created to make inferences in relation to the aspect of embedded individual. The questions "To what extent is the postgraduate education process (courses, counseling, support from other faculty members, etc.) a determinant in building the professional identity of research assistants?" and "What kinds of practices do the (a) university, (b) faculty, (c) department, and (d) division have in relation to how research assistants build their professional identities?" were prepared for the professional identity aspect. The last question of the study, "What deficiencies do research assistants see when building their professional identity?" 
was created for the researchers' curiosity. In the next stage, four faculty members specialized in education management were consulted to ensure content validity, and the final interview form was created in the light of their feedback. In order to test comprehensibility, the final form was implemented over two research assistants who had not been included among the participants and who met the criteria. The pilot study was conducted, and as a result of this implementation, the questions were determined to be clear, plain, and comprehensible.

Research data was collected from research assistants working at a state university in Ankara in December 2015. The data was collected individually using face-to-face interviews. In order to avoid any ethical violations, the researchers drew up an ethical contract and handed it out to all participants. The ethical contract contains information about the researchers' commitment regarding the study's aim, participation in the study being voluntary, interview records only being used for the study, and the records being confidential. The ethical contract facilitated participants' ability to reflect their actual feelings and thoughts on the study's subject and thus helped control tendencies toward exhibiting socially desirable behaviors.

The dates and times for the interviews were determined according to participants' availability. Interviews were carried out in the participants' offices, and each interview took approximately 20-25 minutes. The interview length allowed for obtaining satisfactory answers regarding the study's problem. No one was noted to be in the office during the interview, other than the researcher and participant. In accordance with participants' requests, all interviews were recorded with a voice recorder. Later, the recordings were transcribed and then sent to the relevant participants by e-mail to receive their approval. Following their approval of the interview transcripts, the study proceeded with data analysis.

\section{Data Analysis}

The study data was analyzed using descriptive analysis. First, each interview was transferred to the interview forms without making any changes. While the first part of the interview form contains contextual information (the department where the interview was conducted, the date and time of the interview, research assistant who was interviewed, researcher, interview number, and researcher's interview/field comments), the second part contains the raw data. The raw data form section contains unedited interview transcriptions. Data analysis began with multiple readings of the entire raw data set. Expressions unrelated to the study subject were then determined and removed. This was followed by codification for each interview. In this stage, the raw data sets were examined. Each researcher independently made codings based on the raw data and marked the themes obtained from the data that they found appropriately in accord with the study's aims. Thus, each theme functioned as a 
border where data was processed (Yıldırım \& Şimşek, 2013, p. 256). After coding was completed, codes were compared and reliability was tested. While trying to present the research assistants' thoughts, the researchers assumed an objective role without influencing the participants' thoughts. In this study, the researchers' role is to make explanations by synthesizing the definitions and meanings of the research assistants about how they build their professional identity working in universities.

\section{Validity and Reliability}

In order for the study to produce valid and reliable results, four experts were consulted to ensure the conceptual validity of the data collection tool, and the final form of the tool was shaped according to their feedback. The ethical contract was drawn up in order to control participants' socially desirable tendencies. Expert views were sought during the stages of determining the study group and creating the data collection tool to ensure internal validity and reliability. The literature was reviewed and the study was based on a suitable conceptual foundation while developing the data collection tool. In addition, participant approval was also used to increase the validity of the study. After the interviews are transcribed, these transcriptions are sent to the relevant participants via e-mail and their approval was taken. A faculty member specialized in qualitative research examined the entire process from a critical point of view and provided feedback. One threat to a study's validity is the factor of participant features (Brink, 1993, p. 37; Fraenkel \& Wallen, 2006, p. 170). It was controlled to make sure there was maximum diversity by making plans to minimize the possibility of obtaining biased results from having too many participants with the same or similar characteristics. Location, considered to be another validity threat, was determined as the participants' offices where they were interviewed within the scope of the study. The offices where each interview was conducted were observed to have similar features and conditions, thus the impact of location on the study's results is expected to be lower. Furthermore, each participant was interviewed separately to prevent participants from exhibiting "interaction influence." Meanwhile, Campbell, and Stanley (1963) reported that instrumentalization poses a danger to validity (as cited in Trochim \& Land, 1982). Instrumentalization threats include how results obtained from the data collection tool are evaluated, as well as the characteristics and biases of the person collecting data (Brink, 1993, p. 36; Fraenkel \& Wallen, 2006, p. 173; Lewis, 2009). On this point, in order to prevent the researchers from changing any analysis due to factors such as fatigue from working for too long while analyzing the obtained data (instrument decay), researchers worked in a planned manner in frequent, short intervals. In relation to external validity and transmissibility, the study group, environment, and processes were attempted for detailed definitions, and this information has been given in relation to the steps taken within the study process. For the study's internal reliability and consistency, data was ensured by having each 
researcher codify them twice. Direct quotations were also included with the purpose of reflecting individuals' views. In relation to external reliability and verifiability; data collection tools related to the study, raw data, voice recordings, and codification documents during the analysis stage were kept by the researcher.

\section{Findings}

Data obtained within the scope of the study were analyzed in accordance with predetermined themes. Analysis results are presented in this section.

\section{The Concept of Faculty Member}

In relation to this problem, the participants were asked "What kind of roles, responsibilities, and features should an academician have?" In this respect, participants' views regarding faculty members' roles were primarily discussed. Participants' views were determined to focus on faculty members' roles as instructor and researcher. While expressions such as transfers and shares knowledge, has technical knowledge, well equipped, and has depth in field of expertise were frequently used in relation to the role of instructor, expressions such as enthusiastic about research and questioning, pursues the unknown, and curious stood out in relation to the role of researcher. One of the participants expressed a view in relation to faculty members' researcher role as one who carries out studies within the borders drawn by the mainstream line.

Participant views regarding the responsibilities of faculty members were determined to be expressed as social responsibility, responsible for carrying out research and guidance towards research, and responsible for counseling and educating students. Similarly, the faculty members were also stated to be responsible to the institution and even the country as part of their job. Some of the views stated in this theme are as follows:

They must be hardworking and self-sacrificing, because carrying out a scientific study is not an easy process. It involves literature, the research process, and evaluations. They must be patient because it may take a month, or sometimes a year. (RA2)

Above all, I think they must love their job, because our job requires more effort compared to other professions. We have to do this job day and night. Since we don't have a job with certain working hours, I think that faculty members should love their job a little more. (RA3)

I think they should be flexible in every sense. Their attitude towards life should not be so firm. They should be neither black nor white but flexible. (RA4)

The participants' views about the characteristics of academicians can be listed as questioning; flexible; adaptive to change; open to new ideas, development, and 
collaboration; able to use technology; love their job and their students; have strong human relations; be creative, disciplined, hardworking, self-sacrificing, patient, helpful, and honest; and implement knowledge in life and integrate it publicly.

\section{Factors That Led to Being a Faculty Member}

In relation to this sub-problem, participating research assistants were asked the question, "What factors caused the research assistants to choose this profession?" When analyzing participants' answers, they were mostly determined to be happy to teach; they enjoy it and preferred becoming an academician in order to improve themselves scientifically. Some of the views expressed on this matter are as follows:

The idea of improving myself is quite attractive. I have my Master's Degree, $\mathrm{PhD}$, and associate professor's degree. I like it a lot. This may be a long process, but life is short. Given that, it becomes more attractive. (RA2)

Postgraduate education used to mean learning more and acquiring more experience in the field. I started for this reason but I noticed that this progress and learning has no end, and I liked and enjoyed it. So I chose being an academician. (RA6)

Two participants stated liking the field during their undergraduate education and for that reason preferred becoming an academician in order to contribute to their experience and reach the highest possible position in their fields. One view on this matter is as follows:

I have always been too much of an idealist. Since I have always tried to do my best no matter what I do, I tried to reach the best possible point in this field after I got into the department. (RA3)

One participant stated having experience working in a kindergarten during their undergraduate education and noticing that they couldn't work with this age group based on that experience, thus preferring a work environment where one can work with adults. Some of the participant views on this matter are as follows:

There were people whom we took as role models. For example, especially during my undergraduate education, research assistants who came to our courses and similarly our instructors have been role models for us. But there is not a single name to be mentioned here. (RA1)

I did not get into this department voluntarily. Family matters got me here. My father told me that I should not miss this chance; I could change departments later. I could not refuse my family's preferences. It was not easy to change departments afterwards. Then I tried to figure out what I could do in this field. (RA5)

Secondary factors which were effective in participants' choice of profession were expressed as faculty members' guidance and being role models during undergraduate 
education, family members' guidance, the attraction of opportunities offered by academia, financial matters, the free work environment that universities offer, and concerns about monotony and being assimilated in the system by becoming a teacher within the Ministry of National Education.

\section{Desired Faculty Member Features}

The question asked to the participants in relation to this sub-problem was "What kind of a faculty member do research assistants want to be in the future?" The answers to this question show that students plan to become academicians with a student-oriented profile. Academician profiles that stood out are setting examples for students, paying necessary attention to the courses, getting down to the students' level, trusting students' potential, respecting students, being loved by students, establishing good communication with students, considering students as people in all aspects, empathizing with students, and instilling professional values. In addition to these, participants depicted characteristics they want to have as a faculty member as being able to balance social and individual responsibilities, manage intergenerational conflicts, offer sufficient counseling services, be flexible and creative, have advanced research skills and high levels of interaction with all shareholders, and commit to learning. Some of the participant views on this matter are as follows:

Just like a good teacher needs good communication with school management, students, and parents, a good academician needs good relations with the students and institution or faculty management so that one's work is not interrupted for irrational reasons. (RA2)

Primarily, I give importance to interacting with my students in my job. I try to be a reachable instructor. I ensure that they can come and ask me questions whenever they want. Thus, I can establish better communication with them. It is important for me that the students comprehend what I teach. (RA3)

The participants were also asked which of these academician characteristics they currently have. Most stated having student-oriented characteristics. They stated that they currently have characteristics such as being student friendly, able to understand and solve students' problems, and able to give importance to feedback and establish a balanced relationship with students. Some participant views on this matter are as follows:

In terms of humanistic, personal characteristics, I think I am young and have a lot to learn. For example, I just said that an academician should be patient towards students or whomever one is talking to. I don't think that I have such patience at the moment. I think I personally have sharp edges. Maybe I need to be more positive and optimistic. (RA6)

In terms of student relations, we counsel students or are included in our instructors' courses as assistants. I try to establish that relationship with students in a balanced manner. Being integrated with students and overseeing them. However, my educational philosophy rejects 
both. My relationship with the students is on that balance. I think I suggest something like this as a part of my professional identity. I think I succeed in this. (RA5)

Two participants stated being able to have students carry out independent research; one of them stated having the competence to provide qualified counseling services. One participant stated not currently having the patience or ability to positively approach students, which are required of an academician, and this participant is endeavoring in that direction.

\section{Role of Postgraduate Education in Building Professional Identity}

The question asked to the participants for this sub-problem was "To what extent is the postgraduate education process a determinant in building your professional identity?" While the majority of answers indicate that this process enables learning by means of taking faculty members as role models, there were also comments that this process is important for specializing and improving oneself in the field. When other answers were analyzed, participants stated that this process is useful for aspects such as getting to know the job, adapting to it, acquiring professional discipline, satisfying curiosity, feeding the inquisitive spirit, improving personality traits, self-exploration, learning how to adapt to the dynamics of organizational culture, acquiring different perspectives, cultural acquisition, and social networking.

Participants prefer to improve themselves through the positive and negative attitudes and behaviors they received from faculty members as models during their postgraduate education. Some of the views emphasized by the participants are as follows:

In this process in which I worked as a research assistant, I think some of the most informative instruments were the faculty members and advisors who taught us. You can observe their work pace. You can review their behaviors and attitudes during the course, their approach to the course, their performance at the course, their preparation process for the course, and even their approach to homework. You even observe their seriousness on the deadline of homework. (RA2)

Maybe not in the first years, but after starting to work as a research assistant, our instructors taught us something personally, as well, because we look towards them for thoughts about what kind of an academician we should be. We can learn what we should be or what we should not be from these examples. (RA6)

Research assistants who consider this process as an opportunity to specialize in the field and improve themselves try to increase their professional experience with support from faculty members or advisors in addition to the courses. Some of the research assistants' views expressed on this topic are as follows:

I have seen that all the positive and negative experiences I had in that process contributed to my self- improvement. (RA3) 
The postgraduate education process is quite important for specializing in the field. Any qualifications we acquire in this process are quite important for the future. Advisors are important, the courses we have are important, and even the friends we study with in the group are quite important. (RA2)

According to another participant who indicated that this process is an important step in terms of getting to know and adapt to work, the time spent in postgraduate education was found to be quite important in terms of seeing the difficulties and problems of the job, as well as the discipline required. According to some participants, this process is also productive in terms of improving personality traits such as learning to be patient and tenacious (which must be in a researcher's nature) and smoothing the rough edges (which must be present in an educator). Research assistants who stated they' $\mathrm{d}$ explored themselves and tried to draw a line in that process try to adapt to the dynamics of the organizational culture this way. Participants who acquired different perspectives in that process also have the chance to improve their social network by means of the academic events they attend.

\section{University, Faculty, Department, and Division Practices in Building Professional Identity}

In relation to this sub-problem, the question in the interview form was "What kinds of practices do the (a) university, (b) faculty, (c) department, and (d) division have in relation to building professional identity?" Under the university heading, participants mostly pointed out identity as a source of motivation in addition to the responsibility it imposes on them. University image also provides a significant contribution to research assistants' professional development because it allows them to work with academicians known to be qualified in their fields. Unlike these views, one participant stated that the university is responsible for administrative affairs and not for contributing to building a professional identity. According to this, participant views are as follows:

Plus the university's reputation. Yes, there really is something like that. It is not an empty label. It really has some fulfilling aspects. For example, we have quite a strong staff in my field. At some point, it is the university that maintains this. (RA4)

Our university has made a name for itself. This name entails some requirements. We do not notice it while working here, but when we step out, the impact from the outside needs to be filled in. In other words, it creates a motivation to fulfill these requirements in terms of institutionalism. I think this has an impact on people. (RA7)

Participants stated that the faculty contributes toward working and producing more comfortably in logistical and personnel aspects, as well as holding congresses and supporting projects and scientific research. Moreover, one of the participants stated that social activities such as the Teachers' Day event held by the faculty increases motivation. 
We had a Teachers' Day event. It was quite an ordinary event, but the content of the event was so fulfilling, it excited me and I felt motivated. I think this was a contribution, as well. (RA3)

The basic benefit of the faculty is logistics, I think. I also think that both the university and faculty provide a benefit and function in terms of personnel. Protecting employee rights is also essential in terms of academic development because protecting my working rights will enable me to work and produce more comfortably. (RA7)

Regarding departments, participants emphasized working at a department with a higher consciousness of pedagogical formation provides them with positive contributions. With its objectives and vision, departments encourage research assistants in that direction. Some research assistants' views on this issue are as follows:

Many faculty members are limited in pedagogical formation. For example, engineering department faculty members' knowledge formation is not the same as ours. The most significant factor for me to acquire this consciousness is my department. Being friends with instructors who deal with education, looking at education from different perspectives, benefitting from each other's expertise, and simply having a chat on these grounds all contribute a lot. (RA4)

Participants who think that their division contributes the most in building professional identity agree that seminars held within their division are effective. Similarly, their division has an impact on training professional members and providing professional attitudes, behaviors, and skills. On this issue, the views of the research assistants are as follows:

Whoever knows you best will be the one who helps the best for your development. For that reason, I think that my division plays a large role. (RA2)

In my personality and professional development, my division is the one that gave me an entire vision through its endeavors and practices. (RA4)

Participants stated that the image of their university positively impacts them while building their professional identity. According to this, studying at a good university can be considered a significant factor in shaping research assistants' careers. The responsibility that a university brings helps research assistants work with greater motivation and improve themselves. Faculties also contribute to the professional development of participants by means of congresses, scientific research, and project support. Thus, research assistants who feel financially comfortable have the chance to work under better conditions more freely. Stating that their employee rights are protected by the faculties, research assistants are able to carry out studies and produce more comfortably. Studying at departments with higher pedagogical formation consciousness was also stated to be one of the most important relative factors in 
building professional identity. Thus, participants think that they can be qualified as a good educator, one of the most important conditions of being a good academician.

\section{Deficiencies in Professional Identity Development}

The question asked to the participants in relation to this sub-problem was "What deficiencies do the research assistants see in building their professional identity?" Research assistants stated that the biggest deficiency was mostly being disconnected from practice. According to them, their studies are not able to produce practical solutions, nor do they have the chance to practice theoretical knowledge. This minimizes opportunities for making observations to determine certain problems in the field. Being disconnected from practice also causes future faculty members to feel inadequate in terms of classroom management skills. Related participant views are as follows:

We don't have an environment available for practice, we cannot gain experience. (RA6)

We carry out a lot of work towards practice, but my criticism in relation to being a faculty member can be that. My criticism in relation to the system might be that it is disconnected from practice. I am individually satisfied, but when there is a lack of practice, everything remains theoretical. (RA4)

We are working on education here, but we don't have attempts towards practice. We are training students, which is good. They go to school to experience, but what do we do? To what extent do we have a command of our field? (RA1)

Some of the research assistants evaluated the lack of cooperation and communication within the department as a deficiency. The reason for this is that they think carrying out joint studies will contribute to their professional development by combining people with different perspectives. One participant's view on this matter is as follows:

I think cooperation. If we were more aware of each other, I think we all would develop more by carrying out more mutual studies. (RA6)

Another deficient factor in participants' professional development is their courses. Some participants stated that the quality of their courses during postgraduate education was low, and some of them stated that the low number of courses teaching research methods is an obstacle to carrying out scientific studies. In relation to this matter, participants stated their views as follows:

The courses in the program lack quality; it's a problem. And so many courses are unnecessary, especially having so many for a $\mathrm{PhD}$. (RA7)

Courses are another dimension. We sure learn from courses, but there shouldn't be compulsory courses. These compulsory courses are problematic. I think there shouldn't be compulsory courses, but if it has to be, then there should be a chance to vote. (RA5) 
When examining other research assistants' views on this question, deficiencies in their professional development can be listed as lack of internationalization (international cooperation), lack of discipline, low academic work load, laziness, lack of seriousness, secretarial work preventing academic affairs, lack of project experience, being excluded from administrative decisions, and adverse working conditions. According to the views of the research assistant who stated being disturbed by adverse working conditions, the fact that they have to work in offices with 10-12 people on top of working from 8 am to 5 pm results in loss of motivation, and as a consequence, their developmental process is interrupted.

\section{Discussion and Conclusion}

In this study, the factors determining how research assistants build their professional identity is based on the conceptual framework first structured by Henkel (2000). Within the first theme of the study, research assistants' views on faculty members' roles, responsibilities, and characteristics were investigated. This theme was discussed within the framework of the concept of distinctive individual, one of three components presented in Henkel's conceptual framework. This component enables academicians to become effective professionals and to mature within the process by means of professional education and experiences. Findings show that the participants consider faculty members primarily as an instructor and then a researcher. Participants pointed out the importance of faculty members who transfer their field information and specializations to university students effectively and who maintain a positive, balanced relationship with students. Similarly, Şahin (2014) reported that faculty members' instructor role carries much weight within the classroom and that faculty members implement various educational behaviors in that direction.

In the study's second theme, Henkel's (2000) concept of the distinctive individual was investigated in detail, and in this respect, through the reasons why participants chose to become academicians. The distinctive individual is defined as an individual with an authentic background who is able to position one's self within the framework of preferred moral or ethical values and who is identified with a community that has the same characteristics. In this context, the reasons why participants chose to be academicians were determined to focus on learning in detail and deeply, as well as reaching the highest possible point in their field. In Acar, Nemutlu, Gürhan, and Liman's (2004) study, participating research assistants stated that their reasons for being an academician were mostly to carry out scientific research, improve themselves, work in a peaceful and refined environment, and to gain spiritual satisfaction. Sağlam (2011) presents in a study discussing the burnout levels of academic personnel that those who became academicians voluntarily experience lower levels of burnout compared to those who became academicians as a result of family guidance or 
financial concerns. Therefore, one can say that the reason for preferring a profession affects work life and productivity, and that choosing a job voluntarily is a factor that can be positively evaluated both individually and organizationally.

The study's third theme, the academician characteristics that research assistants desire to have, discusses the second component presented by Henkel (2000), the embedded individual. Henkel states that each distinctive individual is also an embedded individual. According to this, individuals mostly adopt and implement roles where the communities and organizations they are involved in are determinative. Participating research assistants were observed planning to be student-oriented academicians who set examples for their students, lower themselves to the students' level, and believe in their students' potential. In parallel with this finding, Kisa (2013) investigated the ideals of research assistants regarding how they should appear in a metaphor study conducted over 47 research assistants. The most frequently used metaphors for participants' ideals were reported to be the sun, sapling, tree, pomegranate, and bee. Kisa (2013, p. 57) explained that research assistants' most frequently used metaphor is the sun as academicians "enlighten themselves, their surroundings, and the science world with an everlasting energy." Similarly, the common ground for metaphors such as sapling, tree, pomegranate, and bee is that numerous people can benefit simultaneously from them and their productive nature. According to this, research assistants obviously want to be academicians who are loved, set an example, empathize, instill professional values, and most importantly, always keep their knowledge alive and updated, thus contributing to their surroundings.

The fourth theme of the study focuses on the last of the three components suggested by Henkel (2000), professional identity. According to this, while building their professional identity, individuals undergo a mutually interactive process between their individual tendencies towards work and the nature of the work due to their pre-existing identity (Blåka \& Filstad, 2007). Ibarra (1999) mentioned that individuals determine role models while building their professional identity by building an intentional identity. In this respect, research assistants state that they increased their professional development by taking faculty members whose courses they had attended or whose behaviors and attitudes they had observed closely during the postgraduate education process as role models. Discovering how or how not to be a good educator through their observations, research assistants have the opportunity to discover how to set a path for themselves and what the requirements of the job will be during the professional development process. Sweitzer (2009) also emphasized that individuals should observe and adopt the attitudes, actions, behaviors, norms, and values of academicians in their field during postgraduate education and thus build their professional identity by means of organizational socialization. Yaman (2002) stated that research assistants observe faculty members during postgraduate 
and $\mathrm{PhD}$ education; they take them as role models and evaluate their acquired experience from this as an example for their future active learning life. Increasing their personal development through their courses in this field or through support from their advisors, research assistants state that this process contributes to their field specialization. According to Çakar (1997), postgraduate education is an educational activity that trains scientists who research, produce science, and enlighten, as well as researchers who are aware of current research in their field, work to reach new findings, and expand their findings. In accordance with this view, research assistants try to feed themselves in various ways during this process. Research assistants who have the opportunity to get to know their work and explore their own potential during their postgraduate education process also have the chance to note the attitudes and behaviors their work requires by exploring the dynamics of their organization. According to Sweitzer (2009), this process is when individuals learn what being a part of an organization means.

In the fifth theme of this study, Henkel's concept of the professional identity was discussed in detail. In this respect, research assistants' views on the practices of the university, faculty, department, and division on building a professional identity were presented. Professional identity can be built by means of organizational socialization that emphasizes mutual culture transfer between the organization and individual (Tierney \& Rhoads, 1994). Employees who adopt the values and cultures of the organization they work for and the experiences they acquire during this process provide a positive contribution to building their professional identity. Participants emphasize the prestige of their university in developing their professional identity. A wellestablished university that offers the chance to have a good staff in the field motivates the participants, as well as brings a great responsibility for maintaining this image. Working with leading academicians in the field provides a significant contribution to research assistants' professional development. Parallel with this, Vigoda-Gadot, Vinarski-Peretz, and Ben-Zion (2003) stated that employee job satisfaction in organizations with a positive organizational image is positively influenced, as well as job performance (Vigoda-Gadot \& Ben-Zion, 2004). Faculties are effective at protecting employee rights and providing logistic support to research assistants by means of the congresses they organize. Research assistants who attend these have the chance to meet other academicians in their field, as well as the opportunity to monitor various studies. Similarly, these congresses help academicians in terms of social networking, thusly enabling them to improve themselves and approach events from various perspectives. Ibarra et al. (2005) stated that social networks can be benefitted from as identity building mechanisms.

Protecting employee rights has also been a striking subject. Research assistants who feel secure with their employee rights stated they are able to work more comfortably 
and feel more autonomous and productive. Buluş (2004) underlined the need to strengthen employee rights in order to increase academic personnel's motivation. Working in a department that is aware of the importance of pedagogical formation is one of the most important factors influencing research assistants' professional identity development. Participants do not consider a faculty member as only someone who conducts scientific research; they also underline the qualification of being a good educator. In the process of building a professional identity, one's division was considered to be the most important supporter. Because it is in a position to know research assistants best, one's division is responsible for bringing in professional consciousness and educating professionals.

The study's last theme revealed the deficiencies that research assistants see in the process of building a professional identity. The conditions participants most frequently expressed as deficient in building professional identity were their opportunities related to practice being very restricted and feeling disturbed about conducting research disconnected from practice. Participants who are unable to practice what they have learned are disturbed about this, and research assistants who do not have active student experience feel inadequate because they cannot acquire experience. Lack of connections within the department and the resultant inability to work on joint studies or projects negatively affect research assistants. Thinking that working with different academicians will enrich the self, participants stated that academicians should have an integrated or connected role. Örücü and Şimşek (2011) also stated that weak academic cooperation and the consequential weak joint-study culture are common problems for academicians. Acar et al. (2004) stated that almost all research assistants feel there is inadequate communication between divisions in their study. Stating unfavorable working conditions, research assistants stated that colleagues in other divisions are able to work more comfortably while they are under close inspection and that this situation overshadows their perception of justice within the department. Similarly, Bakioğlu and Yaman (2004) reported that an insufficient technological infrastructure and inconvenient work environment adversely affect research assistants' career development.

\section{Suggestions}

Participants' views on their perception of faculty members' roles were seen primarily as educator and then as researcher. It is important that faculty members are able to transfer their knowledge to students and implement ways and methods to facilitate learning. However, some reports and studies published in recent years (i.e., Çetinsaya, 2014) indicate that academic publication performance is quite low and the quality of academic publications has deteriorated over the years, despite the fact that the number of such publications has increased. Therefore, it is necessary to 
pay attention to improving research assistants' potential for academic writing and scientific publication from their very first years at work. In this respect, universities may finance various local or international experts to give seminars or practical training on these matters. Similarly, it is important to show the stages of academic publication and national/international indexes clearly based on practice.

One participant stated that academicians are only able to carry out research within the borders drawn around them and fundamentally they are not free. Similarly, Erdem, Adigüzel, and Kaya (2010) stated that obeying the rules, stability-control, and being closed to innovations and new thoughts are principles that stand out because academicians think that hierarchy and market culture dominate universities. However, universities should have environments where science is produced freely. It is necessary to secure the free scientific environment of universities by means of related units, organizations, and laws, and that academicians are encouraged to produce science without concern. Therefore, it is also considered important to instill this attitude in research assistants. Finally, organizing educational activities such as national and international conferences, symposiums, and so on at certain intervals, in addition to cultural and social activities, at relatively new universities could be productive towards research assistants' professional development. Research assistants are uncomfortable with having an educational process disconnected from practice and not being able to produce practical studies. In this direction, it is necessary to provide environments where research assistants may express themselves better and reflect their learning in practice. Research assistants who have passed their $\mathrm{PhD}$ proficiency may be given the opportunity to teach university students under supervision of a faculty member with legal regulations as subject to the principles and procedures that are a part of one's education. In related disciplines, lack of practice during the professional developmental process can be prevented by supporting research assistants' active participation in educational activities in primary and secondary schools.

\section{References}

Acar, A., Nemutlu, E., Gürhan, G., \& Liman, V. (2004). Hacettepe Üniversitesi Eczacılık Fakültesi araştırma görevlilerinin iş memnuniyeti ve bunu etkileyen faktörler [Research assistants' job satisfaction and the factors that influence this satisfaction at Hacettepe University, School of Pharmacy]. Hacettepe Üniversitesi Eczacılık Fakültesi Dergisi, 24(2), 95-106.

Albert, S., Ashforth, B. E., \& Dutton, J. E. (2000). Organizational identity and identification: Charting new waters and building new bridges. Academy of Management Journal, 25, 13-17. http://dx.doi.org/10.5465/AMR.2000.2791600

Archer,L.(2008). Younger academics' constructions of authenticity, success and professional identity. Studies in Higher Education, 33(4), 385-403. http://dx.doi.org/10.1080/03075070802211729

Atak, H. (2011). Kimlik gelişimi ve kimlik biçimlenmesi: Kuramsal bir değerlendirme [Identity development and identity formation: A theoretical assessment]. Psikiyatride Güncel Yaklaşımlar, $3(1), 163-213$. 
Bakioğlu, A., \& Yaman, E. (2004). Araştırma görevlilerinin kariyer gelişimleri: Engeller ve çözümler [Career developments of research assistants: Obstacles and solutions]. Marmara Üniversitesi Atatürk Eğitim Fakültesi Eğitim Bilimleri Dergisi, 20, 1-20.

Barrow, M. (2006). Assessment and student transformation: Linking character and intellect. Studies in Higher Education, 31(3), 357-372. http://dx.doi.org/10.1080/03075070600680869

Baş, T., \& Akturan, U. (2008). Nitel araştırma yöntemleri: NVivo 7.0 ile nitel veri analizi [Qualitative research methods: Qualitative data analysis with NVivo 7.0]. Ankara, Turkey: Seçkin Yayıncılık.

Baxter Magolda, M. B. (2004). Evolution of a constructivist conceptualization of epistemological reflection. Educational Psychologist, 39(1), 31-42. http://dx.doi.org/10.1207/s15326985ep3901_4

Blåka, G., \& Filstad, C. (2007). How does a newcomer construct identity? A socio-cultural approach to workplace learning. International Journal of Lifelong Education, 26(1), 59-73. http://dx.doi. org/10.1080/02601370601151406

Bramming, P. (2007). An argument for strong learning in higher education. Quality in Higher Education, 13(1), 45-56. http://dx.doi.org/10.1080/13538320701272722

Brink, H. I. L. (1993, December). Validity and reliability in qualitative research. Paper presented at the S. A. Society of Nurse Researchers' Workshop, Royal Agricultural University, Gloucestershire, UK.

Buluş, M. (2004). Pamukkale Üniversitesi öğretim elemanlarında akademik ortam doyum düzeyi [The level of academic setting satisfaction among Pamukkale University academicians]. Pamukkale Üniversitesi Eğitim Fakültesi Dergisi, 16(16), 1-7.

Burke, P. J. (1980). The self: Measurement requirements from an interactionist perspective. Social Psychology Quarterly, 43(1), 18-29.

Burt, R. (1992). Structural holes: The social structure of competition. Cambridge, MA: Harvard University Press.

Çakar, Ö. (1997). Bilim adamı yetiştirme: Lisansüstü eğitim [Training academicians: Graduate education]. TÜBA Bilimsel Toplantı Serileri, 7, 65-75.

Çetinsaya, G. (2014). Büyüme, kalite, uluslararasılaşma: Türkiye yükseköğretimi için bir yol haritası [Growth, quality, internationalization: A roadmap for higher education in Turkey]. Eskişehir, Turkey: Yükseköğretim Kurulu.

Chapman, A., \& Pyvis, D. (2006). Quality, identity and practice in offshore university programmes: Issues in the internationalization of Australian higher education. Teaching in Higher Education, 11(2), 233-245. http://dx.doi.org/10.1080/13562510500527818

Cherry, N. L. (2005). Preparing for practice in the age of complexity. Higher Education Research \& Development, 24(4), 309-320. http://dx.doi.org/10.1080/07294360500284649

Clarke, M., Hyde, A., \& Drennan, J. (2013). Professional identity in higher education. In B. M. Kehm \& U. Teichler (Eds.), The academic profession in Europe: New tasks and new challenges (pp. 7-21). Dordrecht, Netherlands: Springer Science+Business Media. http://dx.doi. org/10.1007/978-94-007-4614-5

Cole, M. S., \& Bruch, H. (2006). Organizational identity strength, identification, and commitment and their relationships to turnover intention: Does organizational hierarchy matter? Journal of Organizational Behavior, 27(5), 585-605. http://dx.doi.org/10.1002/job.378 
Cresswell, J. W. (2013). Nitel araştırma yöntemleri: Beş yaklaşıma göre nitel araştırma ve araştırma deseni [Qualitative inquiry: Choosing among five approaches]. (M. Bütün \& S. B. Demir, Trans. \& Eds.). Ankara, Turkey: Siyasal Kitabevi.

Daresh, J. C., \& Playko, M. A. (1995, April). Mentoring in educational leadership development: What are the responsibilities of the protégés? Paper presented at the Annual Meeting of the American Educational Research Association, San Francisco, CA.

Demirel, S., \& Yegen, C. (2015). Tüketim, postmodernizm ve kapitalizm örgüsü [Consumption, postmodernism and the pattern of capitalism]. Ankara Üniversitesi İletişim Fakültesi Dergisi, 2(1), 115-138.

Dickie, V. A. (2003). The role of learning in quilt making. Journal of Occupational Science, 10(3), 120-129. http://dx.doi.org/10.1080/14427591.2003.9686519

Erdem, R., Adıgüzel, O., \& Kaya, A. (2010). Akademik personelin kurumlarına ilişkin algıladıkları ve tercih ettikleri örgüt kültürü tipleri [Organizational culture types that the academicians perceive and prefer in relevant with their institutions]. Erciyes Üniversitesi IIIBF Dergisi, 36, 73-88.

Fraenkel, J. R., \& Wallen, N. E. (2006). How to design and evaluate research in education (6th ed.). New York, NY: McGraw Hill Publishing.

Glyn, A. (1990). Productivity and the crisis of Fordism. International Review of Applied Economics, 4(1), 28-44. http://dx.doi.org/10.1080/758529333

Guiffe, K. A. (1999). Sand piles of opportunity: Success in the art world. Social Forces, 77(3), $815-832$.

Hains, S. C., Hogg, M. A., \& Duck, J. M. (1997). Self-categorization and leadership: Effects of group prototypicality and leader stereotypicality. Personality and Social Psychology Bulletin, 23(10), 1087-1099. http://dx.doi.org/10.1177/01461672972310009

Hall, D. (1995). Unplanned executive transitions and the dance of sub-identities. Human Resource Management, 34(1), 71-92. http://dx.doi.org/10.1002/hrm.3930340106

Henkel, M. (2000). Academic identities and policy change in higher education. London, UK: Jessica Kingsley.

Henkel, M. (2002). Academic identity in transformation? The case of the United Kingdom. Higher Education Management and Policy, 14(3), 137-147. http://dx.doi.org/10.1787/hemp-v14-art22-en

Henkel, M. (2009). Change and continuity in academic and professional identities. In G. Gordon \& C. Whitchurch (Eds.), Academic and professional identities in higher education (pp. 3-13). New York, NY: Routledge.

Hogg, M. A., Terry, D. J., \& White, K. M. (1995). A tale of two theories: A critical comparison of identity theory with social identity theory. Social Psychology Quarterly, 58(4), 255-269.

Hunter, A. B., Laursen, S. L., \& Seymour, E. (2007). Becoming a scientist: The role of undergraduate research in students' cognitive, personal, and professional development. Science Education, 91(1), 36-74. http://dx.doi.org/10.1002/sce.20173

Ibarra, H. (1999). Provisional selves: Experimenting with image and identity in professional adaptation. Administrative Science Quarterly, 44(4), 764-791.http://dx.doi.org/10.2307/2667055

Ibarra, H., Kilduff, M., \& Tsai, W. (2005). Zooming in and out: Connecting individuals and collectivities at the frontiers of organizational network research. Organization Science, 16(4), 359-371. http://dx.doi.org/10.1287/orsc.1050.0129 
Kaartinen-Koutaniemi, M., \& Lindblom-Ylänne, S. (2008). Personal epistemology of psychology, theology and pharmacy students: A comparative study. Studies in Higher Education, 33(2), 179 191. http://dx.doi.org/10.1080/03075070801916088

Karakütük, K., \& Özdemir, Y. (2011). The assessment of the Scientist Training Project (BIYEP) and Staff Training Program (ÖYP). Eğitim ve Bilim, 36(161), 26-38.

Kısa, N. (2013). Araştırma görevlilerinin metaforik algıları: Kim onlar? Kim olmalılar? [Metaphorical images of research assistants: Who are they? Who they should be?]. Mehmet Akif Ersoy Üniversitesi Eğitim Fakültesi Dergisi, 28, 47-66.

Klenowski, V., Askew, S., \& Carnell, E. (2006). Portfolios for learning, assessment and professional development in higher education. Assessment \& Evaluation in Higher Education, 31(3), 267 286. http://dx.doi.org/10.1080/02602930500352816

Kogan, M. (2000). Higher education communities and academic identity. Higher Education Quarterly, 54(3), 207-216. http://dx.doi.org/10.1111/1468-2273.00156

Lewis, J. (2009). Redefining qualitative methods: Believability in the fifth moment. International Journal of Qualitative Methods, 8(2), 1-14. http://dx.doi.org/10.1177/160940690900800201

Madran, A. D. (2011). Sosyal kimlik ve ayrımcılık [Social identity and discrimination]. In K. Çayır \& M. Ceyhan (Eds.), Ayrımcılık: Çok boyutlu yaklaşımlar [Discrimination: Multi-dimensional approaches] (pp. 73-86). İstanbul, Turkey: Bilgi Üniversitesi Yayınları.

Memduhoğlu, H. B. (2007). Post-Fordist üretim örgütlenmeleri ve işgörenler üzerindeki etkileri [Post-Fordist production organizations and their effects on labor force]. Üniversite ve Toplum Dergisi, 7(4), 1-12.

Moore, R. (2001, July). Policy-driven curriculum restructuring: Academic identities in transition? Paper presented at the 2nd Higher Education Close-Up Conference, Lancaster University, Lancaster, UK.

Örücü, D., \& Şimşek, H. (2011). Akademisyenlerin gözünden Türkiye'de eğitim yönetiminin akademik durumu: Nitel bir analiz [The state of educational administration scholarship in Turkey from the scholars' perspectives: A qualitative analysis]. Kuram ve Uygulamada Eğitim Yönetimi, 17(2), 167-197.

Pachler, N., \& Daly, C. (2003, September). Computer-mediated communication and teachers' professional learning. Paper presented at the British Educational Research Association Annual Conference, Heriot-Watt University, Edinburgh, UK.

Patton, M. Q. (2014). Nitel çalışma tasarımı [Designing qualitative studies]. In M. Bütün \& S. B. Demir (Eds.), Nitel araştırma ve değerlendirme yöntemleri [Qualitative research and evaluation methods] (pp. 209-259). Ankara, Turkey: Pegem Akademi Yayıncılık.

Podolny, J. M., \& Barron, J. N. (1997). Resources and relationships: Social networks and mobility in the workplace. American Sociological Review, 62(5), 673-693.

Pratt, M. G., Rockmann, K. W., \& Kaufmann, J. B. (2006). Constructing professional identity: The role of work and identity learning cycles in the customization of identity among medical residents. Academy of Management Journal, 49(2), 235-262.

Reynolds, C. (1996). Cultural scripts for teachers: Identities and their relation to workplace landscapes. In M. Kompf, W. R. Bond, D. Dworet, \& T. Boak (Eds.), Changing research and practice: Teachers 'professionalism, identities and knowledge (pp. 69-77). London, UK: Falmer Press. 
Rhoades, G. (2007). The study of the academic profession. In P. J. Gumport (Ed.), Sociology of Higher Education. Contributions and Their Contexts (pp. 113-146). Baltimore: The Johns Hopkins University Press.

Riley, A., \& Burke, P. J. (1995). Identities and self-verification in the small group. Social Psychology Quarterly, 58(2), 61-73.

Rogers, J. K. (2000). Temps: The many faces of the changing workplace. Ithaca, NY: ILR Press.

Sağlam, A. Ç. (2011). Akademik personelin sosyo-demografik özelliklerinin tükenmişlik düzeyleri ile ilişkisi [Relationship of socio-demographic characteristics of academicians with their burnout levels]. Mustafa Kemal Üniversitesi Sosyal Bilimler Enstitüsü Dergisi, 8(15), 407-420.

Şahin, M. (2014). Üniversite öğretim elemanlarının sınıf içi öğretimsel davranışlarına yönelik öğrenci görüşlerinin incelenmesi (Çankırı Karatekin Üniversitesi Örneği) [Examine student's opinions about how behave academical staff about educational instructions in the classroom (Çankırı Karatekin University Example)]. Turkish Studies, 9(11), 499-515. http://dx.doi. org/10.7827/TurkishStudies.7530

Stets, J., \& Burke, P. J. (2000). Identity theory and social identity theory. Social Psychology Quarterly, 63(3), 224-237.

Strasen, L. L. (1992). The image of professional nursing: Strategies for action. Philadelphia, PA: J. B. Lippincott Company.

Stryker, S. (1968). Identity salience and role performance: The importance of symbolic interaction theory for family research. Journal of Marriage and the Family, 30(4), 558-564. http://dx.doi. org/10.2307/349494

Sweitzer, V. (2009). Towards a theory of doctoral student professional identity development: A developmental networks approach. The Journal of Higher Education, 80(1), 1-33. http://dx.doi. org/10.1353/jhe. 0.0034

Tajfel, H., \& Turner, J. C. (1986). The social identity theory of intergroup behaviour. In S. Worchel \& W. G. Austin (Eds.), Psychology of intergroup relations (pp. 7-24). Chicago, IL: Nelson-Hall.

Tierney, W. G., \& Rhoads, R. A. (1994). Faculty socialization as cultural process: A mirror of institutional commitment (ASHE-ERIC Higher Education Report No. 93-96). Washington, DC: George Washington University, School of Education and Human Development.

Trochim, W., \& Land, D. (1982). Designing designs for research. The Researcher, 1(1), 1-6. Retrieved from http://www.socialresearchmethods.net/research/Designing\%20Designs\%20 For\%20Research.pdf

Tsushima, T., \& Burke, P. J. (1999). Levels, agency, and control in the parent identity. Social Psychology Quarterly, 62(2), 173-189.

Ünal, Ç., \& İlter, İ. (2010). Sınıf öğretmeni adaylarının lisansüstü eğitime olan tutumları (Fırat, Erzincan ve İnönü Üniversitesi Sınıf Öğretmenliği ABD örneği) [Attitudes of classroom teacher candidates toward graduate education]. Atatürk Üniversitesi Sosyal Bilimler Enstitüsü Dergisi, 14(2), 1-18.

Utku, D. (2014). Sosyal kimlik kuramı ve reklamcılık ile bağı. [Social identity theory and its relation to advertising]. Retrieved from https://www.academia.edu/7295810/Sosyal_Kimlik_ Kuram\%C4\%B1_ve_Reklamc\%C4\%B11\%C4\%B1k_ile_Ba $\%$ C4\%9F\%C4\%B1

Varış, F. (1972). Türkiye'de lisansüstü eğitim (Pozitif bilimlerde) [Graduate education in Turkey (In positive sciences)]. Ankara, Turkey: Ankara Üniversitesi Eğitim Fakültesi Yayınları. 
Vidal, M. (2011). Reworking post-Fordism: Labor process versus employment relations. Sociology Compass, 5(4), 273-286. http://dx.doi.org/10.1111/j.1751-9020.2011.00366.x

Vigoda-Gadot, E., \& Ben-Zion, E. (2004). Bright shining stars: The mediating effect of organizational image on the relationship between work variables and army officers' intentions to leave the service for a job in high-tech industry. Public Personnel Management, 33(2), 201-223. http://dx.doi.org/10.1177/009102600403300205

Vigoda-Gadot, E., Vinarski-Peretz, H., \& Ben-Zion, E. (2003). Politics and image in the organizational landscape: An empirical examination among public sector employees. Journal of Managerial Psychology, 18(8), 764-787. http://dx.doi.org/10.1108/02683940310511872

West, M., Nicholson, N., \& Arnold, J. (1987). Identity changes as outcomes of work-role transitions. In T. Honess \& K. Yardley (Eds.), Self and identity: Perspectives across the lifespan (pp. $287-$ 303). New York, NY: Routledge Publishing.

Wrzesniewski, A., \& Dutton, J. E. (2001). Crafting a job: Revisioning employees as active crafters of their work. Academy of Management Review, 26(2), 179-201.

Yaman, E. (2002). Öğretimde kalite açısından ögrretim elemanlarının ögrretmenlik meslek bilgisi yeterliklerinin değerlendirilmesi (Sakarya Üniversitesi örneği) [The level of the relationship the sufficiency of the academic staff in pedagogic formation and quality in education (The example of Sakarya University)] (Master's thesis, Sakarya University, Sakarya, Turkey). Retrieved from https://tez.yok.gov.tr/UlusalTezMerkezi/

Yıldırım, A., \& Şimşek, H. (2013). Sosyal bilimlerde nitel araştırma yöntemleri [Qualitative research methods for the social sciences] (9th ed.). Ankara, Turkey: Seçkin Yayıncılık. 